\title{
ODH, Oxygen Deficiency Hazard Cryogenic Analysis
}

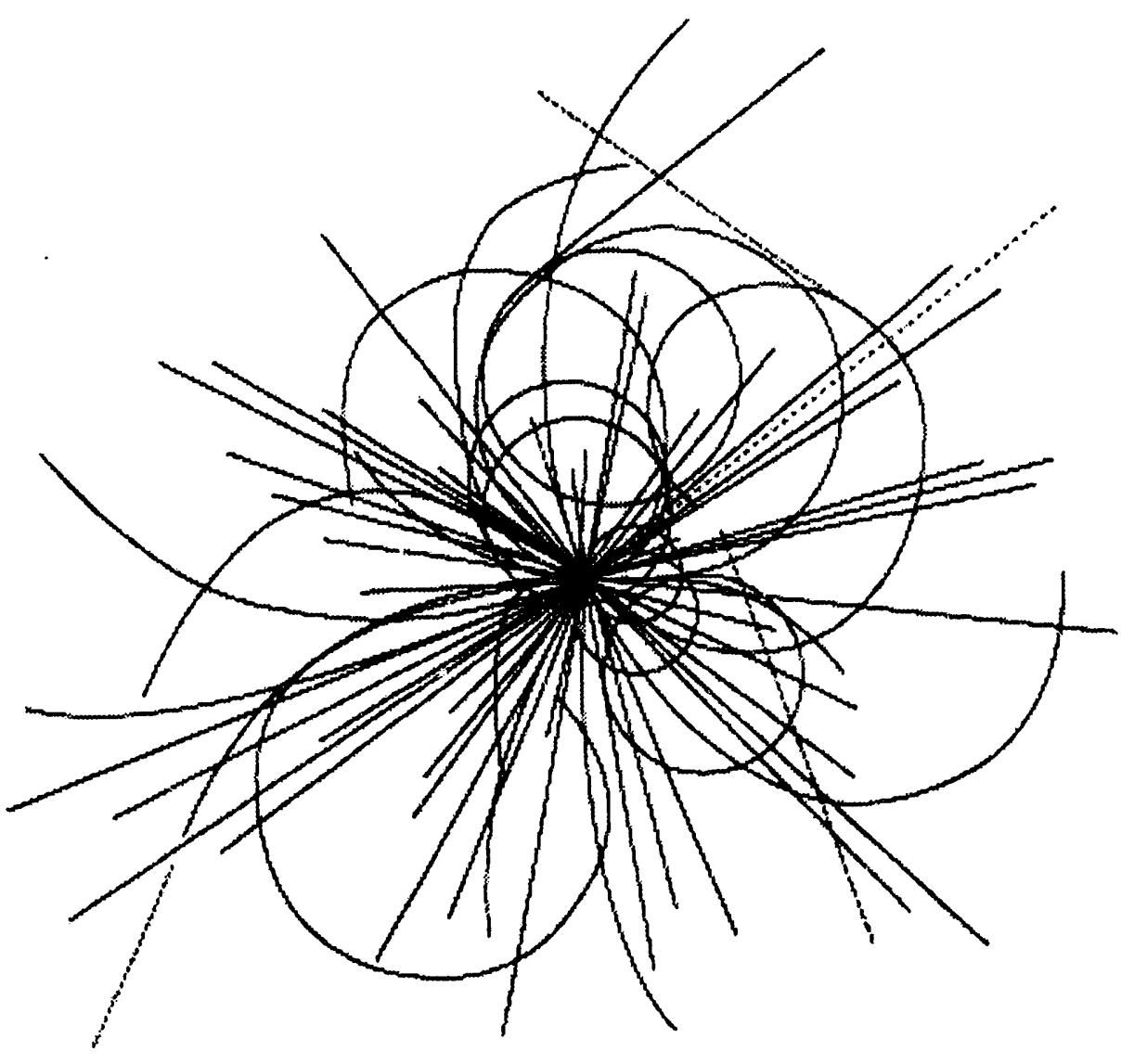

\section{Superconducting Super Collider Laboratory}

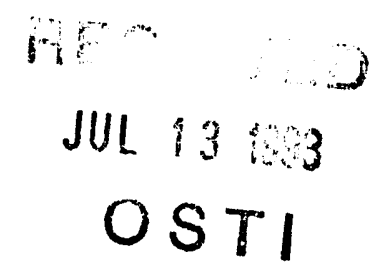




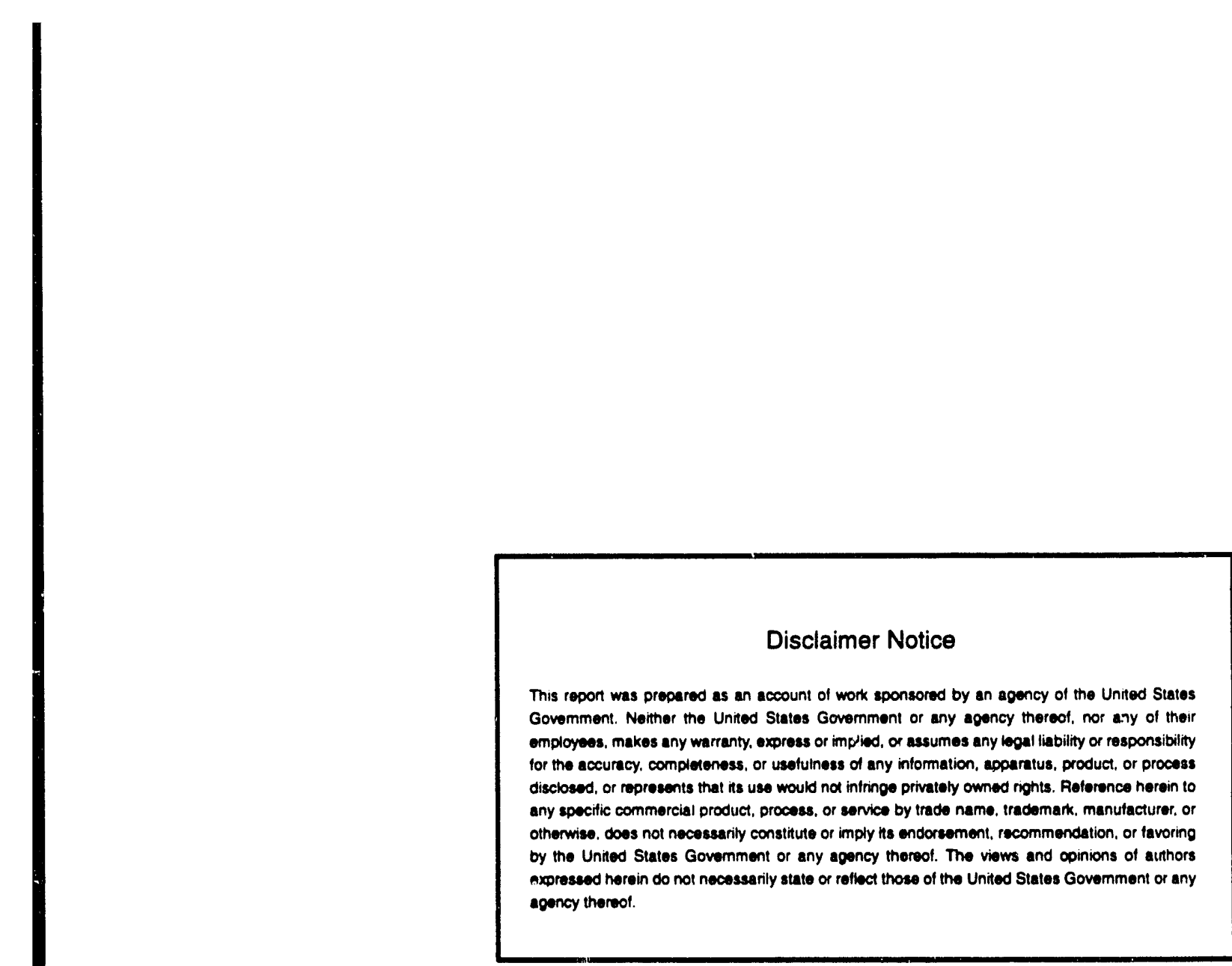

Superconducting Super Collider Laboratory is an equal opportunity employer. 


\title{
ODH, Oxygen Deficiency Hazard Cryogenic Analysis*
}

\author{
S. Augustynowicz \\ Superconducting Super Collider Laboratory ${ }^{\dagger}$ \\ 2550 Beckleymeade Ave. \\ Dallas, TX 75237
}

July 1993

\footnotetext{
"To be presented at the International Cryogenics Engineering Conference, July 12-14, Albuquerque, N.M.

${ }^{+}$Operated by the Universities Research Association, Inc., for the U.S. Department of Energy under Contract No. DE-AC35-89ER40486. 


\title{
ODH, OXYGEN DEFICIENCY HAZARD CRYOGENIC ANALYSIS
}

\author{
Stan D. Augustynowicz \\ Cryogenic Department \\ Superconducting Super Collider Laboratory \\ Dallas, TX 75237-3946
}

\begin{abstract}
An oxygen deficiency exists when the concentration of oxygen, by volume, drops to a level at which atmosphere supplying respiratory protection must be provided. Since liquid cryogens can expand by factors of $700\left(\mathrm{LN}_{2}\right)$ to $850\left(\mathrm{LH}_{\mathrm{e}}\right)$, the uncontrolled release into an enclosed space can easily cause an oxygen-deficient condition. An oxygen deficiency hazard (ODH) fatality rate per hour $(\varnothing)$ is defined as: $\emptyset=\sum \mathrm{N}_{\mathrm{i}} \mathrm{P}_{\mathrm{i}} \mathrm{F}_{\mathrm{i}}$, where $\mathrm{N}_{\mathrm{i}}=$ number of components, $\mathrm{P}_{\mathrm{i}}=$ probability of failure or operator error, and $\mathrm{F}_{\mathrm{i}}=$ fatality factor. ODHs range from "unclassified" $(\varnothing<10-91 / \mathrm{h})$ to class 4 , which is the most hazardous $\left(\varnothing>10^{-1}\right.$ $1 / \mathrm{h})$. For Superconducting Super Collider Laboratory (SSCL) buildings where cryogenic systems exist, failure rate, fatality factor, reduced oxygen ratio, and fresh air circulation are examined.
\end{abstract}

\section{INTRODUCTION}

An oxygen deficiency exists when the concentration of oxygen by volume drops to a level at which atmosphere supplying respiratory protection must be provided. This condition is defined in the "SSCL Oxygen Deficiency Hazards Procedure" to exist when the atmospheric oxygen concentration is less than $19.5 \%$. Since liquid cryogen can expand to room temperature by a factor from $700\left(\mathrm{LN}_{2}\right)$ to $850\left(\mathrm{LH}_{\mathrm{e}}\right)$, uncontrolled release into an enclosed space can easily cause an oxygen-deficient condition. The ODH classes with relation to the fatality rate $F$ are presented in Table 1 .

In order to quantify the degree of hazard associated with an accidental release of cryogen, an ODH fatality rate per hour is defined as:

$$
\Phi=\sum N_{i} P_{i} F_{i},
$$

where $\mathrm{N}_{\mathrm{i}}=$ number of $\mathrm{i}$-type component

$\mathrm{P}_{\mathrm{i}}=$ probability that the $\mathrm{i}$-th component failure or operator error will occur $[1 / \mathrm{h}]$

\footnotetext{
- Operated by the Universities Research Association Inc., for the U.S. Department of Energy under the contract No: DE-AC35-89ER40486
} 
$\mathrm{Fi}_{\mathrm{i}}=$ fatality factor; it is the probability that occurrence of the $\mathrm{i}$-th failure will result in a fatality [fatalities per failure].

Table 1. ODH Classes.

\begin{tabular}{|c|c|}
\hline ODH Class & $\begin{array}{c}\text { Fatality Rate } \Phi \\
1 / \mathrm{h}\end{array}$ \\
\hline Unclassified & $\mathrm{F}<1.0^{*} 10^{-9}$ \\
\hline 0 & $1.0^{*} 10^{-9} \leq \mathrm{F}<1.0^{*} 10^{-7}$ \\
\hline 1 & $1.0^{*} 10^{-7} \leq \mathrm{F}<1.0^{*} 10^{-5}$ \\
\hline 2 & $\frac{1.0^{*} 10^{-5} \leq \mathrm{F}<1.0^{*} 10^{-3}}{1.0^{*} 10^{-3} \leq \mathrm{F}<1.0^{*} 10^{-1}}$ \\
\hline 3 & $\mathrm{~F} \geq 1.0^{*} 10^{-1}$ \\
\hline 4 &
\end{tabular}

\section{CAlculation}

\section{Failure Rates}

The failure rates used are based on Fermi National Accelerator Laboratory (FNAL) experience with the Tevatron, 1.2 manufacturer experience with specific components, and data from the Nuclear Regulatory Commission (NRC). ${ }^{3}$ Use of FNAL statistics is justified by noting that the failure rates are for industry-standard components and are based on data gathered during start-up of the Tevatron. Use of NRC statistics is justified by noting that they were gathered from a variety of sources, including various industrial plants, many of which were designed and built to the same codes as the cryogenic plant. Additional calculations are based on the British Cryogenic Counsel manual, 4 and Superconducting Super Collider Laboratory experience.5,6,7

\section{Fatality Factors}

The fatality factor $F$ is defined for different oxygen concentrations fO2 as follows:

$$
\begin{array}{ll}
\text { for } f \mathrm{O} 2 \leq 0.088, & F=1.00 \mathrm{E}+00 \\
\text { for } \mathrm{fO} 2 \geq 0.180, & F=1.00 \mathrm{E}-07 .
\end{array}
$$

The fatality factor varies continuously as the function of $\mathrm{fO} 2$, over the range:

$$
0.088 \leq \mathrm{fO} 2 \leq 0.180 \text {. }
$$

All exposures with fo2 $\geq 0.18$ are safe and do not contribute to fatality. The lower level fo2 $\leq 0.088$ is the oxygen concentration providing cne minute of useful consciousness. Between these limits, the fatality factor can be given by an exponential function:

$$
F=\operatorname{EXP}(a+b * p * f O 2),
$$

where $p=$ atmospheric pressure [Torr]

$\mathrm{fO} 2$ = fraction of oxygen.

For specific elevations above sea level the atmospheric pressure can be determined as:

$$
\text { Paver }=p_{0} *\left(1-0.0065 * A / T_{0}\right)
$$


where $A=$ elevation above sea level $[\mathrm{m}]$

$\mathrm{T}_{\mathrm{O}}=288.16[\mathrm{~K}]$

$\mathrm{p}_{\mathrm{O}}=101.33[\mathrm{kPa}]$.

To an acceptable level of accuracy the fatality factor can be expressed as the following exponential function of oxygen fraction:

$$
F=\operatorname{EXP}\left(15.417-175.197 * \mathrm{fO}_{2}\right),
$$

when $F=1$ at $\{\mathrm{fO} 2=0.088\}$, and $F=1.00 \mathrm{E}-07$ at $\{\mathrm{fO} 2=0.180\}$.

\section{Oxygen Concentration}

The reduced fraction of oxygen fO2 as a function of time must be known to calculate the fatality factor $F$. In order to approximate the change of fo2 resulting from a cryogen leak into a volume $\mathrm{V}$, the following assumption are made:

1. complete and rapid mixing of all gasses occurs throughout the entire volume

2. the ventilation and leak rates can be approximated as constant

3. the atmospheric pressure in the building remains constant

4. the fresh air supplied to the building contains $21 \%$ oxygen

During the leak the oxygen concertration is given by:

$$
\mathrm{fO}_{2}\left(\mathrm{t}_{\mathrm{r}}\right)=\mathrm{Cr}\left(\mathrm{t}_{\mathrm{r}}\right)=\{0.21 /(\mathrm{Q}+\mathrm{R})\}\left\{\mathrm{Q}+\mathrm{R}^{*} \mathrm{e}^{-\left[(\mathrm{Q}+\mathrm{R})\left(\mathrm{t}^{\prime} \mathrm{V}\right)\right]}\right\}
$$

After the leak has ended the oxygen concentration is given by:

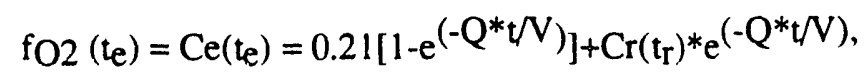

where $V=$ building volume $\left[\mathrm{m}^{3}\right]$

$\mathrm{t}=$ time from the start of the leak release $[\mathrm{s}]$

$\mathrm{R}=$ liquid or gas leak rate as equivalent @ $300 \mathrm{~K}$ and $1 \mathrm{Bar}\left[\mathrm{m}^{3} / \mathrm{s}\right]$

$\mathrm{Q}=$ fresh air circulation rate $\left[\mathrm{m}^{3} / \mathrm{s}\right]$.

The lowest attainable fraction of oxygen for a given leak rate occurs at $t=\infty$, and is given by:

$$
\mathrm{fO} 2(\mathrm{t}=\infty)=0.21\{\mathrm{Q} /(\mathrm{Q}+\mathrm{R})\} \text {. }
$$

When a fixed volume leak is postulated, like emptying a $\mathrm{LHe}$ or $\mathrm{LN}_{2}$ dewar, the fraction of oxygen can be approximated by:

$$
\text { fo2 }(t=\infty)=0.21\left\{\left(\mathrm{~V}-\mathrm{V}_{\text {gas }}\right) / \mathrm{V}\right\}
$$

where $V_{\text {gas }}=$ total volumes of liquid or gas leak as equivalent $@(300 \mathrm{~K}$ and $1 \mathrm{Bar})\left[\mathrm{m}^{3}\right]$.

\section{General Comments}

Cryogenic systems are divided into subsystems, most of which are vacuum insulated. A large internal leak to an insulating vacuum volume will eventually find its way to room air through a relief valve. A worst-case leak rate for an internal component is taken to je equal to the maximum design flow rate for that component.

Failure of cryogenic piping and weld joints can lead to an ODH situation. The total length of pipe is estimated as an average length between major discontinuities (valves, pumps, etc.). To estimate the number of welds, it is assumed that each piece of pipe, each valve, and each reduction joint involves two welds. The total is multiplied by a safety factor of 1.5 to obtain an estimate of the number of internal welds. Since the relevant failure rates 
for lengths of pipe and welds are of order $1 .()^{*} 10^{-9} / \mathrm{h}$, a factor of 2 or 3 in these estimates is seldom crucial. Finally, the worst-case leak rates for either a pipe or a weld failure are taken to be the average maximum flow rate within the appropriate subsystem.

There are a limited number of paths, however, that lead directly to the atmosphere. A subsystem can leak directly to room air through connective piping, valve stems, pressure tap seals, bayonets, etc. In the case of pipe failure, worst-case leak rates are taken to be equal to the maximum design flow rate. In the case of valves, pressure taps, and bayonets, an estimate of the maximum flow achievable is used as the worst-case leak rate. The maximum flow is estimated using worst-case pressure differentials.

The failure rate of a cryogenic fluid line that contains bayonets is estimated to be $3 .()^{*} 10^{-6} / \mathrm{h}$. The NRC failure rates indicate a failure rate of $3.0 * 10^{-6} / \mathrm{h}$ for gaskets and $3.0^{*} 10^{-7} / \mathrm{h}$ for other types of closures. Since a bayonet seal uses a rubber O-ring and $\mathrm{V}$ band, an approximation is made by assuming that a cryogenic fluid line contains two bayonets. Thus, the failure rate of a single bayonet is taken to be $1.5^{*} 10^{-6} / \mathrm{h}$. One additional failure mode associated with bayonets is due to improper installation (operator error). The estimated probability of a large cryogen spill resulting from a U-tube change, calculated by demand, is $1 .(1)^{*} 10^{-3}$. Estimating the demand rate to be on the order of $5.0^{*} 10^{-2} / \mathrm{h}$, a failure rate is $5 .()^{*} 1()^{-5} / \mathrm{h}$.

In all cases, leaking cryogen's are assumed to warm to $300 \mathrm{~K}$ and $1 \mathrm{Bar}$ immediately upon release to the atmosphere. Thus, the leak rate is given by the mass flow rate divided by the appropriate $300 \mathrm{~K}$ and 1 Bar gas density.

\section{EXAMPLE OF ANALYSIS}

A sample set of calculations is presented for a building containing helium compressors with oil skid, helium refrigerator and liquefier, helium distribution box, helium storage tanks, and penetration and connecting pipes.

Basic calculation data are as below. The volume of the building is $2450 \mathrm{~m}^{3}$ (with $10 \%$ less for the volume of the equipment), elevation above sea level is $200 \mathrm{~m}$, and atmospheric pressure is $98.92 \mathrm{kPa}$ (742 Torr). To determine the fatality factor between $\mathrm{O} 2=$ 0.088 and $\mathrm{fO}_{2}=0.18$, the resulting equation is:

$$
F=\operatorname{EXP}\left(15.417-175.197 *_{\mathrm{fO}} 2\right) .
$$

The flow is determined as the maximum liquid or gas cryogen flow from the process data line schedule for a specific subsystem. The failure rate is the value for a specific component and a component failure rate is the value of specific element failure rates multiplied by the numbers of these elements. The leak rate $R$ of cryogen flow is calculated in $\mathrm{m}^{3} / \mathrm{s}$ at room temperature and pressure. The leak ratio is the fresh air circulation (Q) divided by the sum of fresh air circulation (Q) and cryogen leak rate (R). Reduced oxygen ratio is calculated as 0.21 of leak ratio. The fatality rate is the product of component's failure number multiplied by fatality factor.

\section{RESULTS}

Results of the calculation, for the minimum fresh air circulation $Q=0.621 \mathrm{~m} 3 / \mathrm{s}$, are presented in Table 2.

The total fatality rate as a function of the fresh air supply for this case is shown in Figure 1. The minimum ventilation rate consistent with class 0 is $0.621 \mathrm{~m}^{3} / \mathrm{s}$. It is evident from Figure 1 that the fatality rate, with the ventilation system off, is about $1.0^{*} 10^{-4} / \mathrm{h}$. This implies that the supplies and returns fan system of ventilation units must have a probability of failure no greater than $1.0^{*} 10^{-3} / \mathrm{h}$, so that the probability of a leak occurring while HVAC is in some failed state is also less than $1.0^{*} 10^{-7} / \mathrm{h}$. In the case of an on-demand ventilation scheme, the probability that the system fails to come on and run must also be no greater than $1.0^{*} 10^{-4} / \mathrm{h}$. 
Table 2. Fatality rate calculation for fresh air circulation $Q=0.621 \mathrm{~m}^{3} / \mathrm{s}$.

\begin{tabular}{|c|c|c|c|c|c|c|c|c|c|}
\hline $\begin{array}{c}\text { System } \\
\text { Subsystem } \\
\text { Components }\end{array}$ & $\begin{array}{c}\text { N } \\
\text { Compu } \\
\text { nent } \\
\text { Num. }\end{array}$ & Flow & $\begin{array}{c}\text { Failure } \\
\text { Rate }\end{array}$ & $\begin{array}{c}\text { Compo } \\
\text { nents } \\
\text { Failure } \\
\text { Rate } \\
\end{array}$ & $\begin{array}{c}\mathrm{R} \\
\text { Leah } \\
\text { Rate }\end{array}$ & $\begin{array}{c}\text { Q } \\
(Q+R) \\
\text { Leak } \\
\text { Raliu }\end{array}$ & $\begin{array}{l}\mathrm{fO} 2|\infty| \\
\text { Reduced } \\
\text { Oxygen } \\
\text { Ratio }\end{array}$ & $\begin{array}{c}\text { Fatality } \\
\text { Factor }\end{array}$ & $\begin{array}{c}\text { Fatality } \\
\text { Rate }\end{array}$ \\
\hline & & $\mathrm{g} / \mathrm{s}$ & $/ \mathrm{h}$ & $n * P$ & $\mathrm{~m} 3 / \mathrm{s}$ & & & & \\
\hline \multicolumn{10}{|l|}{ Compressor and ril skid } \\
\hline Compressor & 1 & 72 & $1.00 \mathrm{E}-0.5$ & $1.00 \mathrm{E}-0.5$ & 0.4 & 0.58 & 0.12 & $2.28 \mathrm{E} \cdot 03$ & $2.28 \mathrm{E}-10 \mathrm{~K}$ \\
\hline Oil separalor & 1 & 72 & $1.00 \mathrm{E}-06$ & $1.00 \mathrm{E}-06$ & 0.4 & 0.58 & 0.12 & $2.28 \mathrm{E}-0.3$ & $2.28 \mathrm{E}-09$ \\
\hline Oil cooler & 2 & 72 & $1.00 \mathrm{E}-06$ & $2.00 \mathrm{E}-06$ & 0.44 & 0.58 & 0.12 & $2.28 \mathrm{E}-0.3$ & $4.57 \mathrm{E}-(x)$ \\
\hline Oil absorber & 2 & 72 & $1.00 \mathrm{E}-06$ & $200 \mathrm{E} \cdot(6)$ & 0.44 & 0.58 & 0.12 & $2.28 \mathrm{E}-03$ & $4.57 \mathrm{E}-09$ \\
\hline Oil heater & 1 & 72 & $1.00 \mathrm{E} \cdot 06$ & $1.00 \mathrm{E}-06$ & 0.44 & 0.58 & 0.12 & $2.28 \mathrm{E}-03$ & $2.28 \mathrm{E} \cdot(19$ \\
\hline Piping internal & 15 & 72 & $1.00 \mathrm{E}-09$ & $1.50 \mathrm{E}-0 \mathrm{~s}$ & 0.4 & 0.58 & 0.12 & $2.28 \mathrm{E} \cdot 03$ & $3.43 \mathrm{E}-11$ \\
\hline Valves & 10 & 72 & $1.00 \mathrm{E}-08$ & $1.00 \mathrm{E}-07$ & 0.44 & 0.58 & 0.12 & $2.28 \mathrm{E}-03$ & $2.28 \mathrm{E}-10$ \\
\hline Welds & 30 & 72 & $3.00 \mathrm{E}-09$ & $9.00 \mathrm{E}-08$ & 0.44 & 0.58 & 0.12 & $2.28 \mathrm{E}-0.3$ & $2.06 \mathrm{E}-10$ \\
\hline Tank dryer & 1 & 72 & $1.00 \mathrm{E}-06$ & $1.00 \mathrm{E} \cdot 06$ & 0.44 & 0.58 & 0.12 & $2.28 \mathrm{E}-0.3$ & $2.28 \mathrm{E}-09$ \\
\hline Welds & 10 & 72 & $3.00 \mathrm{E}-09$ & $3.00 \mathrm{E} \cdot 08$ & 0.44 & 0.58 & 0.12 & $2.28 \mathrm{E}-0.3$ & $6.85 \mathrm{E}-11$ \\
\hline \multicolumn{10}{|l|}{ Refrigerator and Liquefier } \\
\hline \multicolumn{10}{|c|}{ Internal } \\
\hline Vacuum vessel of refrigeralor & 1 & 72 & $1.00 \mathrm{E}-06$ & $1.00 \mathrm{E}-106$ & 0.44 & 0.58 & 0.12 & $2.28 \mathrm{E}-03$ & $2.28 \mathrm{E} \cdot 09$ \\
\hline Heat exchanger & 6 & 72 & $1.00 \mathrm{E}-06$ & $6.00 \mathrm{E}-06$ & 0.44 & 0.58 & 0.12 & $2.28 \mathrm{E}-03$ & $1.37 \mathrm{E}-08$ \\
\hline Adsorber & 3 & 2 & $1.00 \mathrm{E}-06$ & $3,00 \mathrm{E}-06$ & 0.44 & 0.58 & 0.12 & $2.28 \mathrm{E}-03$ & $6.85 \mathrm{E}-(99$ \\
\hline Surge vessel & 2 & 72 & $1.00 \mathrm{E}-06$ & $2.00 \mathrm{E}-06$ & 0.44 & 0.58 & 0.12 & $2.28 \mathrm{E}-0.3$ & $4.57 \mathrm{E}-(69$ \\
\hline Expander & 2 & 20 & $3.00 \mathrm{E}-06$ & $6.00 \mathrm{E}-06$ & 0.12 & 0.84 & 0.18 & $2.26 \mathrm{E}-\mathrm{M}$ & $1.35 \mathrm{E}-12$ \\
\hline Piping internal & 15 & 50) & $1.00 \mathrm{E} \cdot(x)$ & $1.50 \mathrm{E}-08$ & 0.31 & 0.67 & 0.14 & $1.00 \mathrm{E}-04$ & $1.50 \mathrm{E} \cdot 12$ \\
\hline Welds & 255 & 72 & $3.00 \mathrm{E}-09$ & $7.65 \mathrm{E}-07$ & 0.44 & 0.58 & 0.12 & $2.28 \mathrm{E}-0.3$ & $1.75 \mathrm{E}-(\mathrm{r})$ \\
\hline Filter & 5 & 12 & $1.00 \mathrm{E}-06$ & $5.00 \mathrm{E}-06$ & 0.44 & 0.58 & 0.12 & $2.28 \mathrm{E}-0.3$ & $1.14 \mathrm{E}-108$ \\
\hline \multicolumn{10}{|c|}{ Extemal } \\
\hline Valves & 50 & 72 & $1.00 \mathrm{E}-08$ & $5.00 \mathrm{E}-07$ & 0.44 & 0.58 & 0.12 & $3.28 \mathrm{E}-03$ & $1.14 \mathrm{E}-09$ \\
\hline Welds & 75 & 72 & $3.00 \mathrm{E}-09$ & $2.25 \mathrm{E}-07$ & 0.44 & 0.58 & 0.12 & $2.28 \mathrm{E} \cdot 03$ & $5.14 \mathrm{E}-10$ \\
\hline Pressure tabs & 10 & 30 & $3.00 \mathrm{E}-07$ & $3.00 \mathrm{E}-06$ & 0.18 & 0.77 & 0.16 & $2.35 \mathrm{E}-06$ & $7.04 \mathrm{E}-12$ \\
\hline Bayonets & 4 & 72 & $1.50 \mathrm{E}-06$ & $6.00 \mathrm{E}-06$ & 0.44 & 0.58 & 0.12 & $2.28 \mathrm{E}-03$ & $1.37 \mathrm{E}-08$ \\
\hline \multicolumn{10}{|l|}{ Cold box } \\
\hline \multicolumn{10}{|c|}{ internal } \\
\hline Vacuum vassel & 1 & 50 & $1.00 \mathrm{E}-06$ & $1.00 \mathrm{E}-06$ & 0.31 & 0.67 & 0.14 & $1.00 \mathrm{E}-04$ & $1.00 \mathrm{E}-10$ \\
\hline Cooler & 2 & 50 & $1.00 \mathrm{E}-06$ & $2.00 \mathrm{E}-06$ & 0.31 & 0.67 & 0.14 & $1.00 \mathrm{E}-04$ & $2.00 \mathrm{E}-10$ \\
\hline Cold pump & 1 & 50 & $5.00 \mathrm{E}-06$ & $5.00 \mathrm{E}-06$ & 0.31 & 0.67 & 0.14 & $1.00 \mathrm{E}-04$ & $5.00 \mathrm{E}-10$ \\
\hline Piping internal & 15 & 50 & $1.00 \mathrm{E}-09$ & $1.50 \mathrm{E}-08$ & 0.31 & 0.67 & 0.14 & $1.00 \mathrm{E}-04$ & $1.50 \mathrm{E}-12$ \\
\hline Welds & 150 & 50 & $3.00 \mathrm{E}-09$ & $4.50 \mathrm{E}-07$ & 0.31 & 0.67 & 0.14 & $1.00 \mathrm{E}-04$ & $4.50 \mathrm{E}-11$ \\
\hline \multicolumn{10}{|c|}{ Extemal } \\
\hline Valves & 30 & 50 & $1.00 \mathrm{E}-08$ & $3.00 \mathrm{E}-07$ & 0.31 & 0.67 & 0.14 & $1.00 \mathrm{E}-04$ & $3.00 \mathrm{E}-11$ \\
\hline Welds & 100 & 50 & $3.00 \mathrm{E}-09$ & $3.00 \mathrm{E}-07$ & 0.31 & 0.67 & 0.14 & $1.00 \mathrm{E}-04$ & $3.00 \mathrm{E}-11$ \\
\hline Pressure tabs & 10 & 30 & $3.00 \mathrm{E}-07$ & $3.00 \mathrm{E}-06$ & 0.18 & 0.77 & 0.16 & $2.35 \mathrm{E}-06$ & $7 .(14 \mathrm{E}-12$ \\
\hline Bayonets & 6 & 50 & $1.50 \mathrm{E}-06$ & $9.00 \mathrm{E}-06$ & 0.31 & 0.67 & 0.14 & $1.00 \mathrm{E}-04$ & $9.01 \mathrm{E} \cdot 10$ \\
\hline \multicolumn{10}{|c|}{ GHe storage tank. 68000L@300K and 18Bar } \\
\hline Tank & $\mathrm{I}$ & 5 & $1.00 \mathrm{E}-06$ & $1.00 \mathrm{E}-06$ & 0.03 & 0.95 & 0.20 & $0.00 \mathrm{E}+00$ & $0.00 \mathrm{E}+00$ \\
\hline Valves & 5 & 5 & $1.00 \mathrm{E}-08$ & $5.00 \mathrm{E}-08$ & 0.03 & 0.95 & 0.20 & $0.00 \mathrm{E}+00$ & $0.00 \mathrm{E}+(\mathrm{X})$ \\
\hline Welds & 20 & 5 & $3.00 \mathrm{E}-09$ & $6.00 \mathrm{E}-08$ & 0.03 & 0.95 & 0.20 & $0.00 \mathrm{E}+00$ & $0.00 \mathrm{E}+(\mathbf{X})$ \\
\hline Cuastrophic leaks (calc.per g/s) & 1 & 816 & $1.00 \mathrm{E}-\mathrm{CP}$ & $1.00 \mathrm{E}-09$ & 5.01 & 0.11 & 0.02 & $1.00 \mathrm{E}+00$ & $1.00 \mathrm{E}-(19$ \\
\hline \multicolumn{3}{|c|}{ GHe storage iank. $3800 \mathrm{~L}, 300 \mathrm{~K}$ and $1.2 \mathrm{Bar}$} & & & & & & & \\
\hline Tank & 1 & 1 & $1.00 \mathrm{E}-06$ & $1.00 E \cdot 06$ & 0.01 & 0.99 & 0.21 & $0.00 \mathrm{E}+00$ & $0.00 \mathrm{E}+(\mathrm{x})$ \\
\hline Valves & 5 & 1 & $1.00 \mathrm{E}-08$ & $5.00 \mathrm{E}-08$ & 0.01 & 0.99 & 0.21 & $0.00 \mathrm{E}+00$ & $0.00 \mathrm{E}+10$ \\
\hline Welds & 20 & 1 & $3.00 \mathrm{E}-09$ & $6.00 \mathrm{E}-08$ & 0.01 & 0.94 & 0.21 & $0.00 \mathrm{E}+00$ & $0.00 \mathrm{E}+(0)$ \\
\hline Bayonets & 4 & 1 & $1.50 \mathrm{E}-06$ & $6.00 \mathrm{E}-00$ & 0.01 & 0.99 & 0.21 & $0.00 \mathrm{E}+(0)$ & $0.00 \mathrm{E}+(00$ \\
\hline Callastrophic leaks (cake.per g/s) & 1 & 895 & $1.00 \mathrm{E}-09$ & $1.00 E-09$ & 5.49 & 0.10 & 0.02 & $1.00 \mathrm{E}+00$ & $1.00 \mathrm{E}-09$ \\
\hline \multicolumn{10}{|c|}{ Miscellaneous penetration/connection line } \\
\hline Compressor supply & 1 & 72 & $1.00 \mathrm{E}-09$ & $1.00 \mathrm{E}-09$ & 0.44 & 0.58 & 0.12 & $2.28 \mathrm{E}-03$ & $2.28 \mathrm{E}-12$ \\
\hline Compressor discharge & 1 & 72 & $1.00 \mathrm{E}-07$ & $1.00 \mathrm{E}-09$ & 0.44 & 0.58 & 0.12 & $2.28 \mathrm{E}-03$ & $2.28 \mathrm{E}-12$ \\
\hline $20 \mathrm{~K} /$ Quench & 1 & 200 & $1.00 \mathrm{E}-09$ & $1.00 \mathrm{E}-09$ & 1.23 & 0.34 & 0.07 & $1.00 \mathrm{E}+00$ & $1.00 \mathrm{E}-09$ \\
\hline LHe Storage Dewar & 2 & 4 & $1.00 \mathrm{E}-09$ & $2.00 \mathrm{E}-09$ & 0.02 & 0.96 & 0.20 & $0.00 \mathrm{E}+00$ & $0.00 \mathrm{E}+00$ \\
\hline LHe Feed (as & 2 & 50 & $1.00 \mathrm{E}-09$ & $2.00 \mathrm{E}-09$ & 0.31 & 0.67 & 0.14 & $1.00 \mathrm{E}-04$ & $2.00 \mathrm{E}-13$ \\
\hline GHe return & 2 & 2 & $1.00 \mathrm{E}-09$ & 2.00E-09 & 0.01 & 0.98 & 0.21 & $0.00 \mathrm{E}+00$ & $0.00 \mathrm{E}+00$ \\
\hline LN2 & 2 & 50 & $1.00 \mathrm{i}-09$ & 2.00E-09 & $n .04$ & 0.93 & 0.20 & $0.00 \mathrm{E}+00$ & $0.00 \mathrm{E}+00$ \\
\hline \multirow[t]{2}{*}{ GiN2 } & 2 & 50 & 1.00E-09 & $2.00 \mathrm{E}-09$ & 0.04 & 0.93 & 0.20 & $0.00 \mathrm{E}+00$ & $0.00 \mathrm{E}+00$ \\
\hline & & & & & \multicolumn{4}{|c|}{ Total cryogenic building } & $1.00 \mathrm{E}-07$ \\
\hline
\end{tabular}




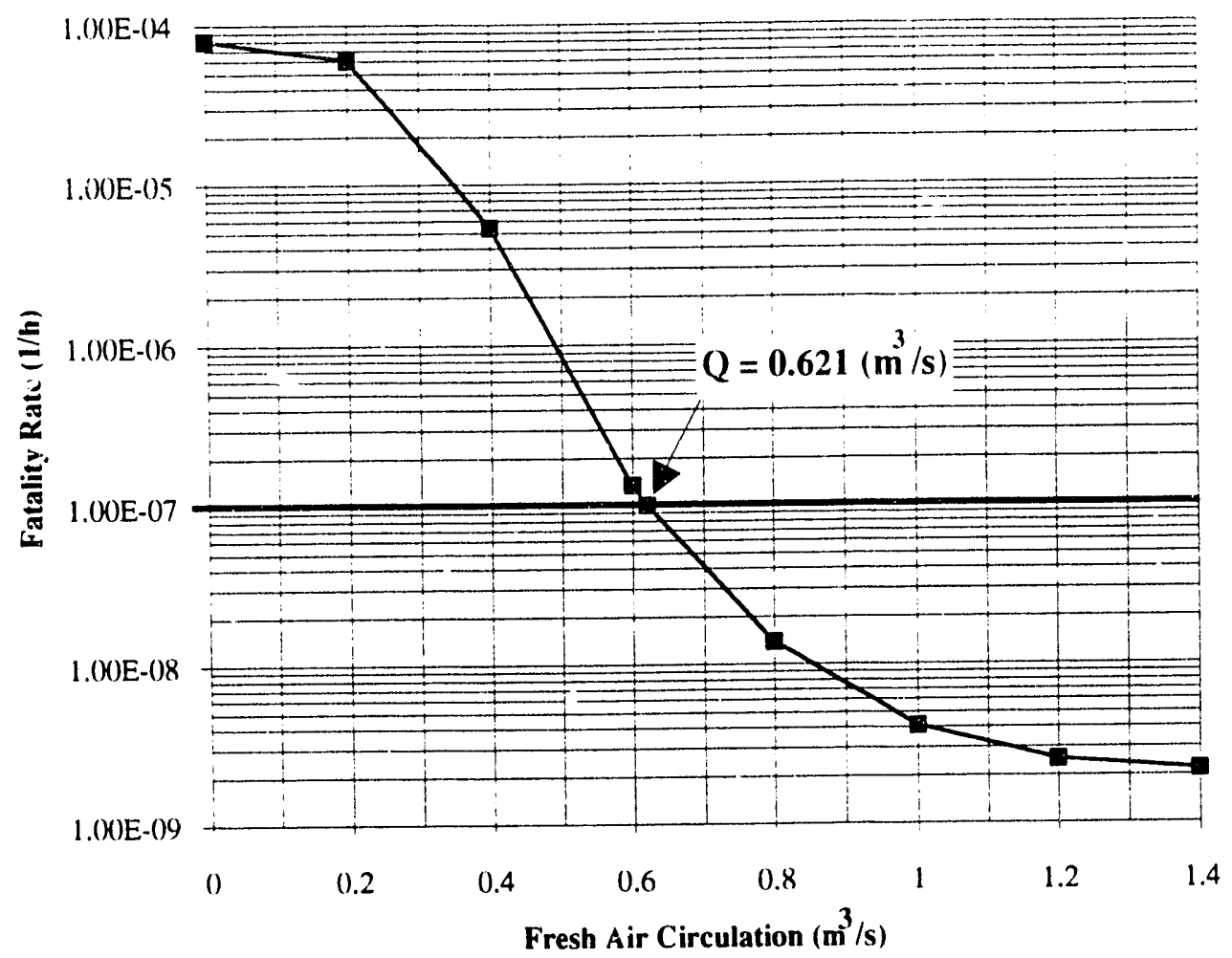

Figure 1. Total fatality rate as the function of fresh air circulation.

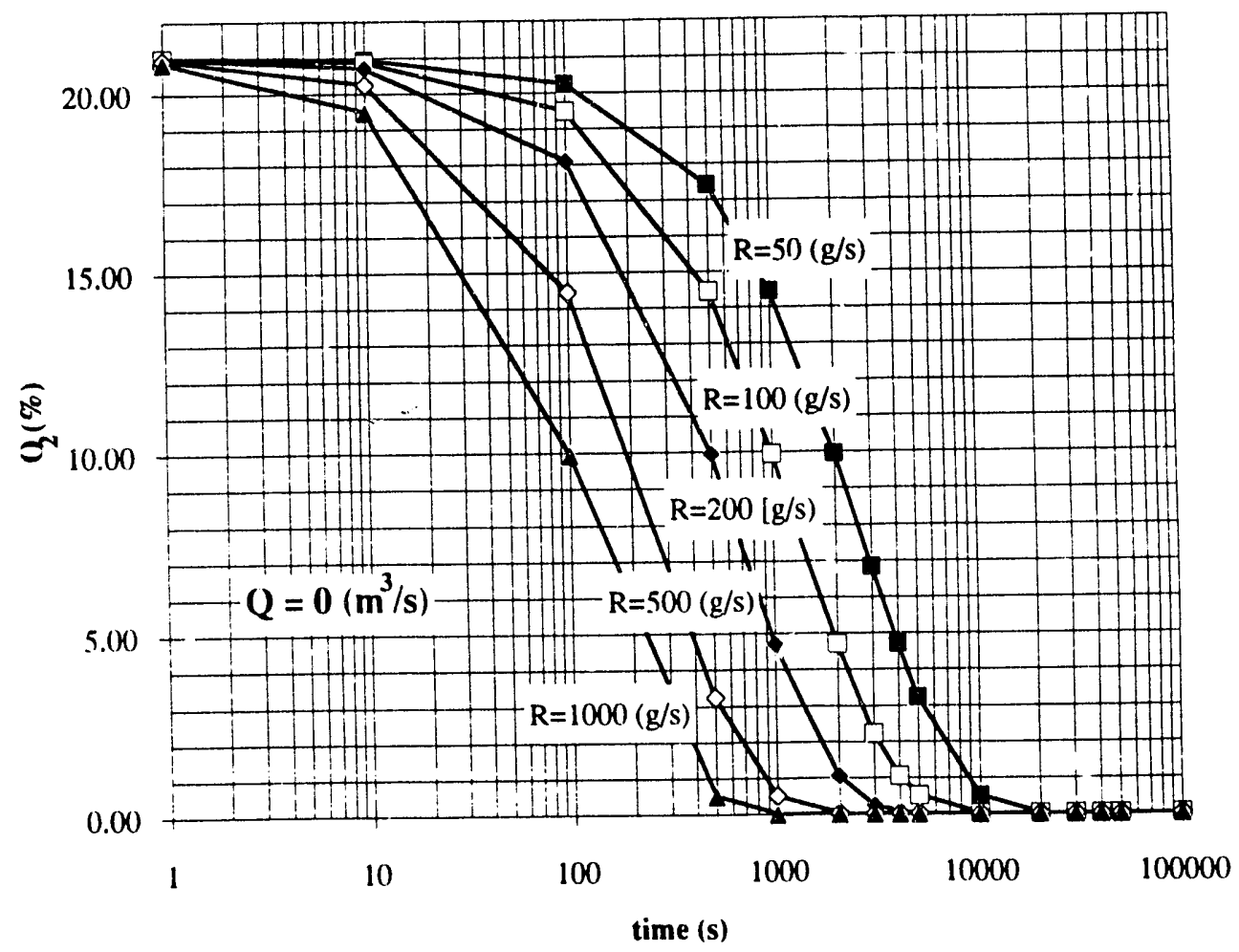

Figure 2. Oxygen concentration as a function of cryogen leak. 
The correlation between oxygen building concentration and real leak time, with assumptions described above, is shown in Fig 2. In this case, ventilation system power is off, and there is no fresh air supply to the building ' $Q=0 \mathrm{~m}^{3} / \mathrm{s}$ ). During the leak, helium gas is concentrated in the upper part of the building, filling one third of the total building volume $\left(\mathrm{V} / 3=817 \mathrm{~m}^{3}\right)$. Leak rates from $100 \mathrm{~g} / \mathrm{s}$ to $1000 \mathrm{~g} / \mathrm{s}$ are included. This figure shows that in the worst catastrophic situation (helium broken line supplies $1000 \mathrm{~g} / \mathrm{s}$ of gas), there is about $100 \mathrm{~s}$ to clear the building of personnel.

\section{CONCLUSION}

A method for determining the fatality rate during leak of cryogen was discussed. The method was demonstrated by applying it to a building with cryogenic equipment. An estimate of the time to evacuate the building was made for a catastrophic evaluation.

\section{ACKNOWLEDGMENT}

Author gratefully acknowledges J. Maddocks, G. Mulholland, and J. Demko for important and helpful conversations and ideas.

\section{REFERENCES}

1. Fermi National Accelerator Laboratory, Safety Manual: "Oxygen Deficiency Hazards (ODH)," Fermi Document No: 5064-1 (1986).

2. J. Mishael and G.T. Mulholland," General ODH analysis method and conclusion," Fermi National Accelerator Laboratory Engineering Note No: EN-3740.510-229 (1989).

3. U.S. Nuclear Regulatory Commission, "Reactor Safety Study: An Assessment of Accident Risks in U.S., Commercial Nuclear Power Plant Appendix 3\&4: Failure Data," (1975).

4. British Cryogenic Council, Cryogenic Safety Manual, Butterworth-Heinemann Ltd., Oxford (1991).

5. S.D. Augustynowicz, J. R. Maddocks and G.T. Mulholland,"ODH oxygen deficiency hazard N15 site analysis," Superconducting Super Collider Laboratory, Document: AHA-8200001 (1992).

6. J.R. Maddocks, S.D. Augustynowicz, and G.T. Mulholland,"Oxygen deficiency hazard analysis for the ASST building," Superconducting Super Collider Laboratory, Document: AHA-9010001 (1992).

7. S.D. Augustynowicz and J.R. Maddocks," ODH oxygen deficiency hazard Magnet Test Laboratory analysis," Superconducting Super Collider Laboratory, Document: AHA(1993). 

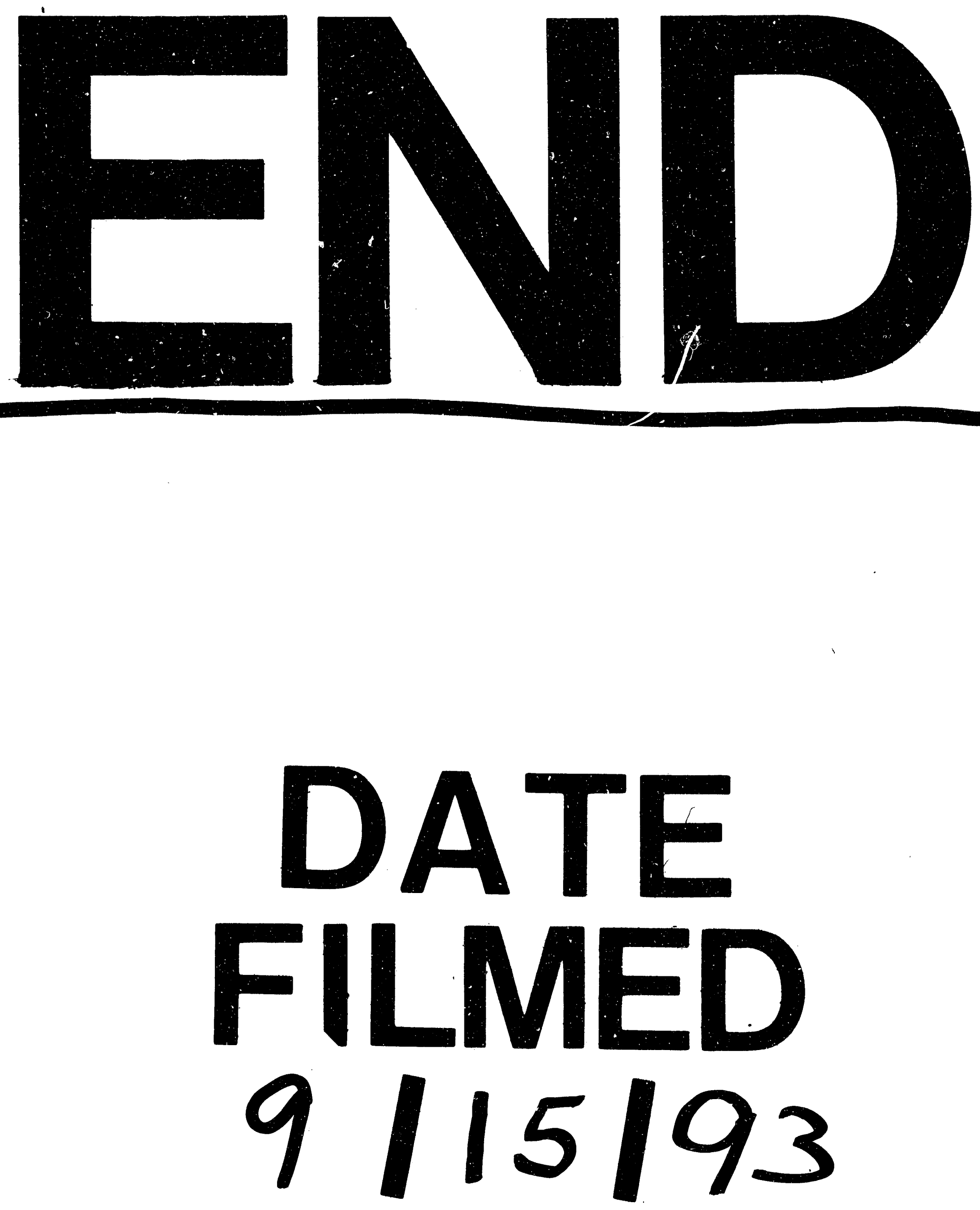
